DOI: https://doi.org/10.31874/2309-1606-2020-26-1-16 УДК 37.018.2

\title{
Богуслав Вольнєвич
}

\section{Захищаймо школи ${ }^{1}$}

Перший український переклад тексту Богуслава Вольнєвича «Захищаймо школи».

Богуслав Вольнєвич $\epsilon$ новою постаттю в українському інформаційному просторі. Цей професор Варшавського та запрошений професор низки провідних американських і європейських

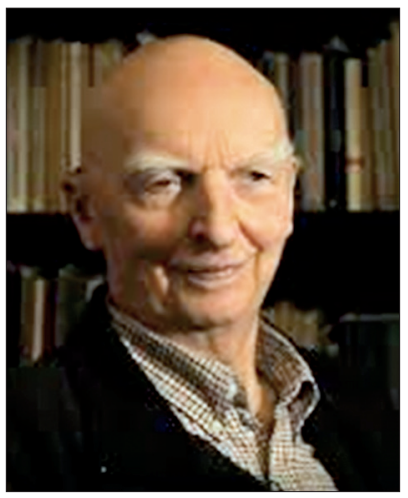
університетів, член міжнародного Віттгенштайнівського товариства, відомий також публіцистичною діяльністю, у тому числі виступами у пресі, на радіо й телебаченні, а також лекціям на каналі ҮоиТиве, де він став став справжньою зіркою Інтернету.

Головні ділянки його думки - логіка, метафізика, етика, філософія релігії та філософія права, але найбільше визнання він здобув як творець онтології ситуації, як перекладач і коментатор Л. Віттгенштайна, а також критик фройдизму, феноменології, постмодернізму, марксизму та релігійного фундаменталізму.

На його думку, шкільна реформа не може руйнувати авторитет вчителя - навіть заради запровадження новітніх закордонних освітніх зразків. Вольнєвич захищає ідеали класичної школи, яка має давати учням науково обгрунтовані знання, а не просто практичні рещепти виживання у суспільстві. Він наголошує, що головним завданням школи є навчання, а виховання може в ній з'явитися лише як цінний побічний продукт - як допінг. Школа виховує тільки через навчання: через його змісти, його рівень, його вимоги і його доцільну організацію. Вольнєвич застерігає від засилля чиновництва у школі, а місію держави бачить у забезпеченні освітньої автономії. Школа не має бути закладом, орієнтованим на прибутки, або ж засобом будування особистої кар'єри якогось чиновника.

Ключові слова: школа, вчительство, реформа школи, класична школа, держава, польська школа.

1. Переді мною лежить розробка «Реформа системи освіти: вступна концепція». Ї̈̈ видало у січні Міністерство національної освіти та підписав міністр Мірослав Гандке. Я дивлюся на цей плід чиновницької винахідливості і думаю: отже варвари, все-таки, перемогли. Розвалять тепер

${ }^{1}$ Перекладено за виданням: Wolniewicz В. (2018) Brońmy szkoły. In: B. Wolniewicz. Filozofia i wartości II. Warszawa: Uniwersytet Warszawski (wydanie II), 275-283. (Олег Гірний, далі - пер.) 
школу до фундаментів, а суспільство прийме цей замах байдуже, ніби не про його дітей і внуки якраз ідеться.

Ця чиновницька «реформа школи» - вінець багаторічної запеклої пресової нагінки на школу та вчительство. [Вона] почалася тридцять років тому, коли у мочарсько-гереківських ${ }^{1}$ колах під впливом китайської «культурної революції» народилася думка, щоб і у нас використати молодь в якості тарана для розбивання політичних противників. Звідти також вийшов потім голосний тоді «рапорт про стан освіти», а також спроби переробития польської школи в радянську «десятирічку». (Перейменування керівників основних шкіл у «директорів» - це тут лише невелика прелюдія.) Гасло кинув тоді пресі (це був, здається, 1967 рік) тижневик «Polityka» - підлою нападкою на директорку ліцею у Вамбжезні, як на нібито винуватицю самогубства одного з учнів. Ліцей мав якнайкращу опінію, але що з того? «Собак спустили з ланцюга». Прикладом може бути [те], як бездумно та завзято топтали тоді доробок Учительських студій. Весною 1979 року знаменитий логік Роман Сушко, тоді вже смертельно хворий, писав мені: «Я знаю, що у пресі постійно займаються шкільництвом, тому у цій галузі є якась дика атмосфера. Вважаю, що висловити свою думку про школу на терені школи - це вже героїзм». Він був правий - і був би правий сьогодні.

2. Декларовані цілі «комплексної реформи школи» є неясними, загальниковими й утопійними. І мають такими бути, бо, як кожна революція - обіцяють «грушки на вербі».

Отож читаємо, наприклад, що «реформа» має спричинити, щоб замість «енциклопедичного навчання» школа «виробляла вміння» і «формувала особистість»; щоб «помічала переживання учня» та витворювала в ньому «почуття власної цінності й придатності»; щоб «була пов'язана зі сім'єю», а також «готувала до самостійного життя, справності й успішності». У ній передбачається також винагороджування вчителів на якомусь, ближче не окресленому, «відповідно високому рівні», а також «належний їм суспільний престиж», який із цієї реформи має якось сам [собою] «випливати». Коротше кажучи, обіцяється туманно та багато.

Декларовні цілі реформи - це тільки декорація вистави - весь час та сама уже кілька десятків років. Проте, коли придивитися ближче, то 3-поза [цих декорацій] прозирають цілі інші - уже цілком конкретні й реальні, от тільки які не дуже підходять, щоб їх показувати прямо. Тому, треба трохи вміти читати між рядків. У цій лектурі може допомгти коментар, що його становлять інтерв'ю міністра Гандке, дане [часописам] «Życie» і «Gazeta Polska». Цих реальних цілей є декілька, щораз віддаленіших.

\footnotetext{
${ }^{1}$ Див. примітку на с. 257 (nер.)
} 
3. Найближча мета - це просто «мавпування» Америки. Як велику новинку оголошують реорганізацію школи: замість 12 років навчання, поділених на 8 [років] основної школи та 4 [роки] ліцею, має бути теж 12, але поділених на 6 [років] основної школи, 3 [роки] гімназії та 3 [роки] - ліцею ${ }^{1}$. Це - механічна копія американської public school, з її поділом на 6 роікв elementary, 3 [років] junior high і 3 [років] senior high. Так само $\epsilon$ і з заміною навчання за природним поділом на предмети («польська мова», «математика» і т.д.) поділом на «інтегровані освітні блоки», де все має бути перемішане: математика з історією, біологія з польською мовою, горох із капустою. Що важливіше - так само є також із «приматом умінь над фактами». (Міністр за іншої нагоди: «Школа має вчити життя, а не фарширувати знаннями».) Тут лише відтворюються застарілі дидактичні ідеї Д'юї столітньої давності. Їх проштовхують так звані «спеціалісти» від педагогіки та психології дитини: ми назвемо їх разом «педологами». (Термін «педологія», тобто «дитинознавство», [що] був уже колись в обігу - теж родом з Америки.)

Зовнішні «реорганізації» нічого у школі не покращать - можуть тільки зіпсувати. Тут хитро використовується засліплення нашого суспільства Америкою. Його не інформують, що тамтешня public school, з iї «практичним уміннями» та «інтегрованими блоками» - це зазвичай жалюгідна школа - набагато гірша за нашу, і хто тільки може, від неї тікає. Американці не дуже знають, що з нею робити, як не знають, що робити 3 «трущобами» - цією виразкою на тілі їхніх великих міст. Могутня Америка тут стоїть безрадною. А наші безтурботні реформатори замінюють нам добру польську школу на поганеньку американську школу - майже як ото «дядько» $з$ прислів'я ${ }^{2}$.

В інтерв’ю для «Gazety Polskiej» міністр глумиться з польської школи, що діти у ній вчаться [того], «як збудована євглена [зелена], але не знають, що мають робити в банку». Це - демагогія та заклик до знищення. Як може міністр освіти висміювати працю вчителя біології, який із найкращими намірами та згідно з програмою старається на прикладі цього найпростішого [організму] пояснити молоді чудо життя. А що було б краще? Може взагалі на вводити їх у таємниці природи, а тільки вчити змалку «як порахувати прибуток і у що інвестувати»? Страшна це ментальність, як для міністра освіти. Його попередники мали досить сенсу, щоб цю проблематичну «реформу» тихенько блокувати. (У розробці го-

\footnotetext{
${ }^{1}$ Обговорювана автором реформа проводилася у Польщі з 1991 по 2001 рік. 32014 року, в рамках нової (!) реформи, польську школу реорганізувано у 8-річну основну та 4-річний ліцей. (О.Г.)

${ }^{2}$ Автор тут має на увазі польську приказку «wymienił stryjek siekierkę na kijek» (дослівно «поміняв дядько сокирку на кийок») - відповідник української приказки «поміняв дядько шило на швайку». (nер.)
} 
вориться, що «досі не було достатньої волі до запровадження її в життя».) Цей, навпаки, хоче її форсувати «з великою рішучістю». Це якнайгірше віщує школі.

4. Друга мета лежить глибше. Цією метою є остаточне розбиття класичної школи та її далі ще живих традицій. То завдяки їм наша школа далі ще непогано функціонує, а, беручи до уваги те, як колоди їй кидають під ноги - функціонує навіть дуже добре. Та нічого, треба її розбити остаточно, бо, згідно з педологами, вона $є$ перешкодою для «самореалізації» та завадою у «вільній експресії особистості». Тому, геть їі!

Кому це так потрібно? Таких $є$ багато, адже міністр тут не є сам. За ним стоять цілі загони лібералів і лібертинів різної масті, що прямують, в ім'я «сучасного гуманізму» і щораз новіших «прав людини» до повної «деконструкції» будь-якої дисципліни та будь-якого авторитету. I насамперед у школі.

Ось що каже часописові «Życie» сам міністр, згадуючи свої шкільні роки: «Була неймовірна дисципліна. Дівчат засуджували за стилонові ${ }^{1}$ панчохи; коли вони тупірували волосся, пані професор могла розплести зачіску. Була вся та ідіотська система дисципліни, невідомо навіщо». Так бачить польську школу та її вчительство їхній міністр: це - громада тупих недоумків, що тільки й можуть «фарширувати знанням» і «розплітати зачіски». Це - мова вулиці, а водночас ще й страшенна брехня, бо в класичній школі не було нічого «ідіотського». Було привчання до скромності, до не вихваляння свої одягом перед біднішими друзями та подругами: у школі ви всі рівні, для стилонів і тупірування ще прийде час; не все відразу. Можна сперечатися, чи така виховна мета була слушною. Але брехнею $є$, що це робилося «невідомо навіщо». Бо добре відомо.

5. Третя мета - допоміжна: бажаючи розбити класичну школу, треба вдарити по її носіях, тобто по вчительству. Про це подумали.

Насамперед, далі йде нагінка на вчителів. Прикладів є багато, ось один. У радіопрограмі «Клуб Трійки» (11.12.1997) ми почули, що «75\% шкільного знання є непотрібним», що «агресія вчителів» породжує агресію учнів і що «більшість учителів $є$ не на своєму місці». Зате з несмаком було прийнято телефонний дзвінок якоїсь молодої, але розсудливої слухачки, яка [сказала,] що «коли ви так говоритимете, що через три роки буде страшно зайти у клас без поліціянта». (На цьому похмурому фоні

1 Стилон - поліамідне волокно для виготовлення тканин, трикотажу, панчішношкарпеткових виробів; інші назви: «капрон» (Росія, Україна), «нейлон» (США, Британия), «дедерон», «перлон» (Німеччина), «лаліон» (Італія), «грілон», «амілан» (Японія), «силон» (Чехія), «ефілон» (Угорщина). (пер.) 
лише одне вирізнялося позитивно: католицька преса не дала втягнути себе в цю нагінку.)

Вся медійна кампанія на користь так званої «дружньої школи», була повністю та винятково анти-вчительською. Ніхто на ставив і не ставить питання про відповідальність за школу всіх тих міністрів, державних секретарів, директорів департаментів, начальників відділів, інспекторів, інструкторів і «спеціалістів». Так, ніби вони не мають із цим нічого спільного.

Кажуть, що програми $є$ перевантаженими. Правильно, але хто їх так перевантажив? Адже не вчителі, а тільки чиновники та їхні «спеціалісти». Ті, що роками постійно втручалися у програми, безоглядно ламали будь-який розсудливий опір вчителів, аж допровадали до повного розхитування. [...] I після такої компрометації беруться тепер, ніби нічого не сталося, за нову «реформу», яку запроваджуватимуть так само брутально й невміло як тамті. До цього питання ми ще повернемося.

6. Підбурювання проти вчительства - це, однак, щойно увертюра, пропагандивний вступ і мобілізація сил для справжнього удару. Ось він: передбачається «радикальна верифікація статусу вчителя». Говорячи ясніше, це означає (це чітко видно з «Вступної концепції»), що планується цілковита дестабілізація професійного становища та життєвої ситуації вчителя.

3 цією метою вигадали шестиступеневу драбину посад, даючи їм для маскування оздобні назви «вчитель спеціаліст», «вчитель дипломований», а на вершині «професор освіти»(!). Проте, з-під цього камуфляжу видно, що на жодному з цих щаблів учитель не матиме посадової стабільності. Кожного, з «професором освіти» включно, можна буде легко усунути - звичайним повідомленням, довшим чи коротшим, якщо для влад і їхніх педологів він виявиться «непридатним». (Наприклад, коли [він] недостатньо настирливо реалізуватиме їхню «реформу», або дозволить собі слово критики - то його легко витіснять.)

До таких витіснень добре приготувалися. Вчитель має проходити цілу систему «стежок оцінювання», яка кожному, хто зіткнувся колись із беззаконням освітніх влад і їхньою брутальністю, мають неуникно асоціюватися з відомими «стежками здоров’я»ํ. Просовувані цими стежками будуть не добрі вчителі, а тільки слухняні та корисні, бо це, вочевидь, означатиме в практиці «бездоганну морально-етичну позицію». А над

${ }^{1}$ Стежка здоров'я - іронічне окреслення форми тортур, застосовуваних у ПнР Службою безпеки, SB, загонами міліції особливого призначення та Народною міліцією, особливо до діячів опозиції; полягали у вдаряння кийками арештанта, який біжить між двома рядами тих, хто б’є. (nер.) 
усіма зависне батіг чиновницької сваволі, що підстьобуватиме до щораз більшого зусилля - і то в безглуздо наміченому напрямку.

Це ніякі не домисли, це говориться прямо. Так, наприклад, у своєму інтерв’ю для «Gazety Polskiej» міністр Гандке обрисовує план примушування вчителів до інтенсивної праці. Отож, треба «платити зарплату упродовж не 12 місяців, а [лише] упродовж стількох, скільки триває навчання - але більшу. А у ті два місяці хай учитель має свободу у пошуках собі роботи. А на канікулах хай поїде [з дітьми] в табір або підвищує кваліфікацію, щоб підвищити категорію. Це, врешті, має бути система, в якій функціонують принципи здорового глузду». - Ага, забрати в учителя платну відпустку, потім із його грошей дати декому надбавки. I так змусити його до більшого зусилля - хіба це не геніально?

7. Говорячи про цілі «реформи», пам'ятаймо ще про одне. Отож, для декого вона має певні побічні наслідки - дуже бажані, хоча дещо компрометуючі. Придивимося до них.

Для чинного вчителя «реформа школи» - це життєвий катаклізм: підрив методики, яку він опанував і випрацював довгими роками практики та самоосвіти. Тепер йому велять працювати інакше, та не говорять як ${ }^{1}$.

Зовсім інакше є для чиновника і педолога: для них «реформа» - це жниво і просування у вигоді. Адже не вони будуть їі реалізувати, ані нести її тягар; вони її тільки «впроваджуватимуть», тобто будуть підганяти вчителів. А це значить, що буде потреба у великих кількостях нових програм, підручників, директив, циркулярів, навчальних посібників, інструкцій і рекомендацій, семінарів і курсів, формулярів і правил. Треба буде також інтенсивно інспектувати і кваліфікувати, контролювати та верифікувати. Роботи передбачається на роки. За неї ж підуть неодмінно нові посади й договори, проекти і контракти, відрядження, службові надбавки, нагороди й ордени, відзнаки й кар'єрні зростання. Коротше кажучи, гроші і значення. На додачу це - цілковито безпечний маневр, бо коли через кілька років ця «комплексна реформа» закінчиться комплексним крахом - нічого страшного. Зробиться наступна, а провину за фіаско цієї звалять на знову на вчителів - як досі [робили]. Я коли хтось із них захотів би протестувати, то його візьмуть на управлінську «стежку оцінок» - і по крику.

Чим більше реформ, тим гірше для школи та вчителя, і тим краще для педолога й чиновника. Що є дивуватися, що останні до неї рвуться, а перші ні? Є незмірно характерним, що за всі ці роки ганебного наклепництва на школу у пресі та вчителів, з боку освітніх влад не піднявся жоден голос на їх захист; ані з боку педологів. Видно злослів'я було їм на руку.

\footnotetext{
${ }^{1}$ Див.: статтю автора „Слово у справах школи”. (ред.)
} 
8. Остання зі справжніх цілей «реформи» - найсуттєвіша, хоча й дуже загальна. Це навіть $є$ не стільки свідомо обрана мета, скільки спонтанне тяжіння у певний бік. Його суть коротко викладає гасло, яке ніколи голосно не проголошувалося: більше влади чиновницькій касті та її сателітам! Назвемо це «етатистським тяжінням». (Етатизм - це стремління державного апарату до постійного розширення сфери своєї влади. Ї̈̈ кульмінацією є тоталітарна держава.)

У міністерській розробці дух етатизму добре видно. Треба тільки вміти його розпізнати. Отож, там постулюється «створення незалежної від школи системи та принципів оцінювання й екзаменування». Задумаймося, що це означає.

Головним завданням школи $€$ навчання. Виховання може в ній з'явитися лише як цінний побічний продукт - як допінг. Школа виховує тільки через навчання: через його змісти, його рівень, його вимоги і його доцільну організацію. Інших засобів немає. (Можливість виховання безпосередньо через «акцентування» на ньому - наприклад, через часті «виховні бесіди» - це педагогічне марення, наперед приречене на невдачу.)

Щоб учити й виховувати, школа має всі чотири названі елементи процесу навчання зосередити у своїх руках. Відсутність хоча б одного руйнує навчальний і педагогічний ефект усіх решта. Це - ніби чотири необхідні рушії школи, які тільки прикладені разом можуть дати правильний виховний результат: освічену та порядну людину.

Одним із чотирьох рушіїв є навчальні вимоги. Це означає, що в школі, тобто в учителя - колективно й індивідуально - має бути влада екзаменувати, оцінювати та просовувати. «Дуже добре», «добре», «задовільно», «незадовільно» - так екзаменує нас життя, суворо та об’єктивно. Тому школа, яка цей рушій серйозно використовувала, була школою життя, в якій кожен відчував повагу, не один - вдячність, а дехто навіть любов. Зате новомодна школа «радісної гри» і «виховання без поразок» - це штучний заповідник, який прикривається жахливою ідеологічною брехнею. То чи треба дивуватися, що так її бачить молодь, і що ставиться до неї зі зростаючою зневагою та ненавистю? Дивуватися треба було б, якби було інакше.

Цієї влади оцінювання й просування, педагогічно такої абсолютно необхідної, етатистські «реформатори» хочуть тепер школу позбавити. Навіщо? Вочевидь для того, щоби взяти її самі. І засядуть потім, особисто чи через своїх «любих друзів», у різних «незалежних» екзаменаційних комісіях «центрального й регіонального» рівня, і розділятимуть плоди вчительської праці: добрі «дядечки», які бережуть невинну молодь від учительської «агресії». Облуда цієї «реформи» мерзенна. 
9. Та на цьому не кінець. У міністерській розробці вирисовується вже дальша спроба, хоча ще обережна, прощупувальна. Сіллю в оці державного апарату з давен-давна $€$ автономія вищих шкіл; передусім університетів, бо вони є мірою та зразком для інших [вищих шкіл]. Однак, цей наріжний камінь свободи науки має величезну традицію, і навіть комуністичній державі не цілком вдалося її переламати. Але етатизм - це не тільки комунізм, його тяжіння є постійним уже 200 років.

У розробці читаємо, що «реформою» має бути послідовно охоплене усе «поле освіти - від дошкілля до аспірантури». Відтак вищі школи також. Що у справі вищих студій хоче мати що сказати чиновник - неясно. (Як неясними є багато інших питань, наприклад, величина вчительської зарплати, або плановане відношення мінімальної вчительської зарплати до середньої по країні.) Видно одне - що він хоче втручатися у вищі школи, хоч вони у нього не втручаються.

Справа дещо прояснюється в одному-єдиному місці. Про те, хто для даних студій, згідно наукових стандартів даного ВИШу, підходить чи не підходить, досі вирішували самі ці ВИШі через різні форми вступного іспиту. Відтак, у них була влада прийняти когось до себе на студії, або не прийняти. Це належало до їхньої автономії. Отож тепер цьому кінець! У розробці читаємо expressis verbis ${ }^{1}$, що для кандидатів на студії ВИШ не має права організовувати вступний екзамен. То хто ж про це вирішуватиме? Очевидно, що оті комісії, які проводять свої «незалежні від школи» випускні зовнішні іспити [на атестат зрілості]. Відтак, про прийняття до ВИШу вирішуватиме чиновник із нанятим собою педагогом - згідно з їхніми стандартами. Таким чином нога у двері академічної автономії буде вже вставлена. Потім доставиться друга.

Отець Бохенський - цей тверезий розум, писав у 1986 році:

«Чиновники - це могутній клас, що складається в більшості з паразитів та визискувачів. Чисельність і сила цього класу постійно зростає. Клас чиновників - це різновид суспільного раку, який розростається за рахунок здорового організму i, як рак, убиває його, якщо не буде припинено його розвиток.» ${ }^{2}$

Розпочата якраз у Польщі «комплексна реформа системи освіти»це перекидання етатистського раку на організм школи. Сама школа від нього уже не захиститься.

$*$

\footnotetext{
${ }^{1}$ Expressis verbis (лат.) - дослівно. (пер.)

${ }^{2}$ Див.: Bocheński, J. (1992) Sto zabobonów. Krótki filozoficzny słownik zabobonów. Kraków: Philed, 134. (5.B.)
} 
Все це не означає, що в школі та навколо неї немає що робити. $€$, і навіть багато що. Але «комплексних реформ» польській школі безумовно непотрібно.

\section{Богуслав Вольневич. Давайте защищать школы}

Первый украинский перевод текста Богуслава Вольневича «Давайте защищать школы».

Богуслав Вольневич - это новая фигура в украинском информационном пространстве. Этот профессор Варшавского и визитинг профессор ряда ведущих американских и европейских университетов, член международного Виттгенштайновского общества известен также своей публицистической деятельностью, в т.ч. выступлениями в прессе, на радио и телевидении, а также лекциями на канале YouTube, где он стал настоящей звездой интернета.

Главные сферы его мысли - логика, метафизика, этика, философия религии и философия права, но наибольшее признание он получил как творец онтологии ситуации, как переводчик и комментатор Л. Виттгенштейна, а также как критик фрейдизма, феноменологии, постмодернизма, марксизма и религиозного фундаментализма.

По его мнению, школьная реформа не может разрушать авторитет учителя - даже ради внедрения новейших зарубежных образовательных образцов. Вольневич защищает идеалы классической школы, которая должна давать ученикам научно обоснованные знания, а не просто практические рецепты выживания в обществе. Он подчеркивает, что главной задачей школы является обучение, а воспитание может в ней появиться только как ценный побочный продукт - как допинг. Школа воспитывает только через обучение: из его содержания, его уровень, его требования и его целесообразную организацию. Вольневич предостерегает от засилья чиновничества в школе, а миссию государства видит в обеспечении образовательной автономии. Школа не должна быть учреждением, ориентированным на доходы, или же средством построения личной карьеры какого-то чиновника.

Ключевые слова: школа, учителя как класс, реформа школы, классическая школа, государство, польская школа.

\section{Boguslaw Wolniewicz. Let's protect schools}

The first Ukrainian translation of the text by Boguslaw Wolniewicz " Let's protect schools".

Boguslaw Wolniewich is a new figure in Ukrainian information space. This Warsaw professor and visiting professor at a number of leading American and European universities, a member of the International Wittgenstein Society, also known for his journalistic activities, including appearances in the press, radio and television, and lectures on YouTube where he became a real star of the Internet. 
The main areas of his thought were logic, metaphysics, ethics, philosophy of religion and philosophy of law, but he gained the most recognition as the creator of the ontology of the situation, as translator and commentator of Ludwig Wittgenstein, as well as a critic of freudianism, phenomenology, postmodernism, marxism and religious fundamentalism.

In his opinion, school reform cannot destroy the authority of a teacher - even for the sake of introducing the latest foreign educational models. Wolniewicz defends the ideals of the classical school, which should give students scientifically sound knowledge, not just practical recipes for survival in society. He emphasizes that the main task of the school is education, and education can appear in it only as a valuable by-product - as doping. The school educates only through learning: through its content, its level, its requirements and its appropriate organization. Wolniewicz warns against the dominance of bureaucracy in the school, and sees the mission of the state in ensuring educational autonomy. A school should not be a profit-oriented institution or a means of building the personal career of an official.

Key words: school, teachers as a class, school reform, classical school, state, Polish school.

Богуслав Вольнєвич (1927-2017), доктор філософії (хабілітований), професор, польський філософ і логік, автор перекладів на польську мову праць Людвіга Вітгенштейна і автор коментарів до Вітгенштейна. 31989 по 1998 р очолював кафедру філософії релігії Варшавського Університету, 3 1998 - почесний професор того ж університету.

Boguslaw Wolniewicz (1927-2017), Doctor of Philosophy (hab.), professor, Polish philosopher and logician, author of translations into Polish translation by prats Ludwig Vitgenstein and author of comments to Vitgenstein. From 1989 to 1998 he became an Professor Emeritus at the Department of Philosophy of Religion of Warsaw University, from 1998 - Professor Emeritus of the same University. 